\title{
Recent advances in $\mathrm{CD8}^{+}$regulatory $\mathrm{T}$ cell research (Review)
}

\author{
YATING YU $^{1 *}$, XINBO MA $^{1 *}$, RUFEI GONG ${ }^{1 *}$, JIANMENG ZHU $^{2}$, LIHUA WEI $^{1}$ and JINGUANG YAO ${ }^{1}$ \\ ${ }^{1}$ Department of Medical School, Guangxi University of Science and Technology, Liuzhou, Guangxi 545005; \\ ${ }^{2}$ Department of Chunan First People's Hospital, Hangzhou, Zhejiang 310000, P.R. China
}

Received August 13, 2017; Accepted February 1, 2018

DOI: $10.3892 / \mathrm{ol} .2018 .8378$

\begin{abstract}
Various subgroups of $\mathrm{CD}^{+} \mathrm{T}$ lymphocytes do not only demonstrate cytotoxic effects, but also serve important regulatory roles in the body's immune response. In particular, $\mathrm{CD}^{+}$regulatory $\mathrm{T}$ cells $\left(\mathrm{CD}^{+}\right.$Tregs), which possess important immunosuppressive functions, are able to effectively block the overreacting immune response and maintain the body's immune homeostasis. In recent years, studies have identified a small set of special $\mathrm{CD}^{+}$Tregs that can recognize major histocompatibility complex class Ib molecules, more specifically Qa-1 in mice and HLA-E in humans, and target the self-reactive $\mathrm{CD}^{+} \mathrm{T}$ cells. These findings have generated broad implications in the scientific community and attracted general interest to $\mathrm{CD}^{+}$Tregs. The present study reviews the recent research progress on $\mathrm{CD} 8^{+}$Tregs, including their origin, functional classification, molecular markers and underlying mechanisms of action.
\end{abstract}

\section{Contents}

1. Introduction

2. Origin of $\mathrm{CD}^{+}$Tregs

3. Classification and functions of $\mathrm{CD}^{+}$Tregs

4. Common marker molecules

5. Mechanism of action of inhibitory $\mathrm{CD}^{+}$Tregs

6. Recent research progress on $\mathrm{CD}^{+}$Tregs

7. Summary and applications

Correspondence to: Professor Jinguang Yao, Department of Medical School, Guangxi University of Science and Technology, 257 Liushi Road, Liuzhou, Guangxi 545005, P.R. China

E-mail: yao7760698@126.com

*Contributed equally

Key words: $\mathrm{CD}^{+}$regulatory $\mathrm{T}$ cells, immune regulation, Qa-1, $\mathrm{CD} 8 \alpha \alpha^{+}$, autoimmune disease

\section{Introduction}

Immunization is critical for the maintenance of biological homeostasis. It refers to the physiological function by which a body's immune system fights against the invasion of foreign substances and distinguishes internal components from external ones. The immune system is responsible for the body's immune response and immune function. While it produces robust immune responses to attack various antigens, it also negatively regulates or inhibits abnormal immune responses, maintaining a relatively stable immune reactivity (1-3). The immune system consists of three major components, namely the immune organs, immune cells and immunologically active substances. In particular, immune cells are produced, mature and are concentrated in the immune organs. These cells can be divided into phagocytic cells and lymphocytes, which are composed of $\mathrm{T}$ and $\mathrm{B}$ cells that mature in the thymus and bone marrow, respectively. Immunologically active substances mainly refer to antibodies, lymphokines and lysozyme (4-6).

Physiologically, the tolerance of internal components and the response to 'non-self' antigens are under the strict control of the body's immune regulation mechanism. Immune regulation is crucial for the maintenance of the physical environment stability in the human body $(7,8)$. Therefore, dysfunction of immune regulation will result in serious pathological consequences. For instance, if the immune system develops a strong immune attack on the body's own components, autoimmune diseases occur $(9,10)$. The body may also be harmed if the immune system cannot respond adequately to an infection caused by external pathogenic microorganisms. In this case, a weak response can result in severe infection, whereas an excessively strong response can result in allergy (11-18). Therefore, immune regulation determines the occurrence and the strength of an immune response. This elegant and complicated regulation functions in multiple steps in an immune response process.

In 1970, Gershon and Kondo (19) identified CD8 ${ }^{+}$regulatory $\mathrm{T}$ cells $\left(\mathrm{CD} 8^{+}\right.$Tregs). Later studies revealed the dual effects of these cells in immune responses. They have been reported to inhibit the immune response to pathogens and the host's inflammation following pathogen infection. However, by weakening the body's immune surveillance on malignant cells, the host can be relieved from autoimmune diseases (20-22). Although $\mathrm{CD}^{+}$Tregs were recognized $>40$ years ago, little is known regarding their function in negative regulation (23). 
Furthermore, recent studies on $\mathrm{CD} 8^{+}$Tregs revealed their crucial role in immunology (24-26), while CD8 $\alpha \alpha^{+} \mathrm{T}$ cell receptor (TCR) $\alpha \beta^{+}$Tregs, a novel subtype of $\mathrm{CD} 8^{+}$Tregs, was demonstrated to recognize the major histocompatibility complex class Ib (MHC-Ib) molecules Qa-1 in mice. Tregs only target activated $\mathrm{T}$ lymphocytes, and are considered to complement the inhibition function of $\mathrm{CD}^{+}$forkhead box $\mathrm{P} 3$ (FoxP3) $^{+}$Tregs $(27,28)$. Therefore, further studies on CD8 $\alpha \alpha^{+}$ Tregs may provide novel therapeutic strategies for human inflammatory diseases, tumor immunity, transplant tolerance and autoimmune diseases.

\section{Origin of $\mathrm{CD8}^{+}$Tregs}

In the process of thymic negative selection, only $\mathrm{T}$ cell clones with high affinity to autologous antigens are removed $(29,30)$. Therefore, certain $\mathrm{T}$ cells with low affinity to autologous antigens are leaked to the peripheral immune system. Under certain conditions, they may be activated and result in autoimmune diseases. Therefore, this process is monitored by a series of peripheral immune tolerance mechanisms, including Tregs with immunosuppressive effects, namely $\mathrm{CD} 4^{+}$and $\mathrm{CD} 8^{+}$ Tregs (31-33).

\section{Classification and functions of $\mathrm{CD8}^{+}$Tregs}

To date, there is no reliable surface marker that is able to distinguish $\mathrm{CD} 8^{+}$Tregs from ordinary $\mathrm{CD} 8^{+} \mathrm{T}$ cells. In different experimental systems, $\mathrm{CD} 8^{+}$Treg surface molecules have been demonstrated to differ. For instance, in an experimental autoimmune encephalomyelitis (EAE) model, CD8 ${ }^{+} \mathrm{CD} 28^{-}$Tregs demonstrated an inhibitory effect on the secretion of interferon (IFN) $\gamma$ by myelin oligodendrocyte glycoprotein-specific $\mathrm{CD}^{+} \mathrm{T}$ cells through cell contact inhibition $(34,35)$. Similarly, $C D 8{ }^{+} \mathrm{CD} 45 \mathrm{R}^{+}$and $\mathrm{CD} 8^{+} \mathrm{CD} 122^{+} \mathrm{T}$ cells also possess regulatory suppressor functions, including suppression of immune activity following autologous mixed lymphocyte reaction activation (36-38). In comparison, $\mathrm{CD} 8^{+}$Tregs induced by plasma-like dendritic cells (DCs) in the ascites of cancer patients are featured the interleukin (IL)-10 ${ }^{+} \mathrm{C}-\mathrm{C}$ motif chemokine receptor 7 (CCR7) $)^{+}$ $\mathrm{CD} 45 \mathrm{RO}^{+} \mathrm{CD}^{+}$phenotype. In particular, by secreting IL-10, $\mathrm{CCR} 7^{+} \mathrm{CD} 45 \mathrm{RO}^{+} \mathrm{CD}^{+}$Tregs inhibit the function of effective $\mathrm{T}$ cells that specifically attack tumor antigens (39-41). In addition, immature DCs induce the generation of $\mathrm{CD} 8^{+}$ Tregs, while FoxP $3^{+}$antigen-specific $\mathrm{CD}^{+} \mathrm{CD} 28^{-} \mathrm{T}$ cells can also be produced in vitro through rendering vascular endothelial cells tolerogenic (42-45). Notably, inhibitory $\mathrm{CCR} 7^{+} \mathrm{CD} 45 \mathrm{RO}^{+} \mathrm{CD}^{+} \mathrm{T}$ cells can originate from human tumor tissues, indicating their potential association with tumor-induced immune tolerance $(46,47)$.

$\mathrm{CD} 8{ }^{+}$Tregs in humans are predominantly $\mathrm{CD} 8^{+} \mathrm{CD} 28$ Tregs; however, two $\mathrm{CD} 8^{+}$Tregs subgroups can be produced by induction in vitro, namely $\mathrm{CD} 8^{+} \mathrm{CD} 28^{+}$and $\mathrm{CD} 8{ }^{+} \mathrm{CD} 28$ Tregs $(48,49)$. Currently, the majority of studies conducted have investigated $\mathrm{CD} 8^{+} \mathrm{CD} 28^{-}$Tregs, and three categories of these cells have been identified. Among them, type I cells have a direct contact with DCs to influence the expression of the costimulatory molecules CD80 and CD86, demonstrating a negative regulatory role. However, the inhibitory function of type II cells is exerted through cytokine secretion, such as IFN- $\gamma$ and IL-6, while direct contact with antigen-presenting cells (APCs) has not been observed. Finally, type III cells function by secreting IL-10 (50-52).

\section{Common marker molecules}

Common molecules that serve as markers for Tregs include FoxP3, CD25, CD127, CD39 and CD73. Among them, FoxP3 is a member of the fork-like transcription factor family and was first reported in 2001 by Brunkow et al (53). Studies have identified that FoxP3 expression and function are closely correlated with Tregs. FoxP3 is mainly expressed in lymphoid organs and tissues, including in the thymus, spleen and lymph nodes (54-56). In mice, FoxP3 has been reported to be preferentially expressed in $\mathrm{CD} 4^{+} \mathrm{CD} 25^{+} \mathrm{T}$ cells, while its expression in $\mathrm{CD}^{+} \mathrm{T}$ cells was limited. By contrast, in humans, FoxP3 can be expressed in both $\mathrm{CD} 4{ }^{+} \mathrm{CD} 25^{+} \mathrm{T}$ cells and $\mathrm{CD} 8^{+} \mathrm{T}$ cells $(57,58)$. However, its expression in $\mathrm{CD}^{+} \mathrm{T}$ cells is significantly higher in comparison with that in $\mathrm{CD} 8^{+} \mathrm{T}$ cells. Thus far, FoxP3 has been recognized as the most sensitive marker of Tregs (54-56).

Traditionally, the identification of Tregs mainly relied on CD25 labeling. However, it was later reported that identifying Tregs merely based on CD25 positivity was not accurate $(59,60)$.

CD127, an IL-7 receptor, is downregulated in a subset of $\mathrm{CD} 4^{+} \mathrm{T}$ cells in the peripheral blood. These cells are FoxP3 positive, and CD25 weak positive or negative (61). The combination of CD4, CD25 and CD127 selection generates high purity Tregs, which exhibit a strong signal in functional inhibition tests. The population of Tregs that can be distinguished by $\mathrm{CD} 4$ and $\mathrm{CD} 127$ expression (including $\mathrm{CD} 25^{+} \mathrm{CD} 4^{+}$and $\mathrm{CD} 25^{-} \mathrm{CD} 4^{+}$cells) is three times as large as the $\mathrm{T}$ cell sub-population that can be selected by $\mathrm{CD} 4{ }^{+} \mathrm{CD} 25^{\text {hi }}(62)$. As $\mathrm{CD} 127$ has been successfully applied to quantify the Tregs of patients, it has been proposed as a marker of human Tregs $(63,64)$.

Studies have also reported that Foxp $3^{+}$Tregs express the cell surface CD39 and CD73 molecules simultaneously $(65,66)$. When cell damage or apoptosis occurs, intracellular ATP is released, causing increased concentration of extracellular ATP. As the signaling molecules for cell damage, they activate a variety of immune responses. Furthermore, CD39 and CD73 are extracellular enzymes that are expressed by various immune cells, including DCs, B cells and T cells. Notably, they dephosphorylate ATP or AMP, as well as decompose AMP, thus achieving an immunosuppression function and inhibition of T cell inflammatory factors (67-69).

\section{Mechanism of action of inhibitory $\mathrm{CD8}^{+}$Tregs}

Different types of $\mathrm{CD} 8^{+}$Treg subsets can function by secreting various inhibitory cytokines and chemokines, including IL-10, transforming growth factor (TGF) $\beta$, IL-16, IFN- $\gamma$ and chemokine (C-C motif) ligand 4 (33,70-77). CD8 ${ }^{+} \mathrm{CD} 28^{-}$Tregs render the APCs tolerogenic by upregulating the expression levels of immunoglobulin-like transcript (ILT) 3 and ILT4, which then function as cell surface inhibitory receptors. These tolerogenic APCs demonstrate an anti-inflammatory function. The downregulation of costimulatory molecules CD80 and CD86 on 
APCs by $\mathrm{CD}^{+} \mathrm{CD} 28^{-}$Tregs also inhibits the immune response of $\mathrm{CD}^{+} \mathrm{T}$ cells. In addition, CD80 and CD86 are important for the inhibitory function of $\mathrm{CD}^{+} \mathrm{CD} 122^{+} \mathrm{T}$ cells (78-80). Certain subsets of $\mathrm{CD}^{+}$Tregs exert an inhibitory function by cell contact-dependent mechanisms, in which TGF- $\beta$ and cytotoxic T-lymphocyte associated protein 4 (CTLA-4) expressed on the cell surface serve key roles $(81,82)$. CD ${ }^{+}$Tregs exert a cytotoxic effect against antigen-activated $\mathrm{CD} 4^{+} \mathrm{T}$ cells, and this function depends on the expression of the $\mathrm{MHC}-\mathrm{Ib}$ molecule Qa-1 in mice (HLA-E in humans) $(28,83,84)$. The aforementioned mechanisms are presented in Fig. 1A-D.

\section{Recent research progress on $\mathrm{CD8}^{+}$Tregs}

Recent advances. The recent research progress on $\mathrm{CD}^{+}$Tregs mainly includes the aspects presented in Fig. 1E. Briefly, CD $8^{+}$ Tregs have been reported to inhibit autoimmune diseases, to potentially originate from the thymus, to negatively regulate activated $\mathrm{T}$ cells, to supervise the immune tolerance and to be associated with the management of autoimmune diseases.

Exploration of Qa-1-restricted $C D 8^{+}$Tregs in autoimmune diseases. The mouse protein Qa-1 (homologous to HLA-E in humans) is essential for immune protection and immune regulation. In particular, Qa-1-restricted $\mathrm{CD}^{+}$Tregs recognize the MHC-Ib molecule Qa-1, and therefore inhibit the development and recurrence of autoimmune diseases $(27,85)$. Notably, the immune response phenotype of Qa-1-deficient mice demonstrated two opposite effects: Enhanced CD4-dependent immune responses revealed the influence of Qa-1 target loss on $\mathrm{CD}^{+}{ }^{+}$Treg activity, whereas a weakened CD4-dependent immune response demonstrated an unimpeded NKG2A-Qa-1/Qdm inhibition $(86,87)$.

In order to illustrate the two Qa-1-dependent regulatory pathways, researchers performed experiments with Qa-1-deficient mice expressing different surface determinants $(88,89)$. Notably, Qa-1 D227K is a mutant of Qa-1 that interferes with the binding of Qa-1 and CD8 co-receptors to prevent the expression of $\mathrm{CD}^{+}$cell effective molecules. As expected, Qa-1 D227K-deficient mice generated no active CD8 ${ }^{+}$ Tregs, accompanied by worsened EAE symptoms. In addition, Qa-1/Qdm was demonstrated to bind to CD94/NKG2A on $\mathrm{CD}^{+}$Tregs, and may thus suppress the inhibitory activity of $\mathrm{CD}^{+}$Tregs through signaling factors $(90,91)$. Therefore, the key for preventing $\mathrm{CD}^{+} \mathrm{T}$ cell autoimmune responses may be the regulation of Qa-1-restricted auto-activated cells through interaction between Qa-1-Qdm and CD94/NKG2A. It was also reported that the interaction of Qa-1-NKG2A with antibodies in EAE mice attenuated the pathogenic condition to complete remission $(89,92)$. These findings demonstrated that Qa-1 serves a key role in the development and mediation of $\mathrm{CD}^{+}$Treg activity. Furthermore, a molecular level inhibitory mechanism emerged based on these results, suggesting that MHC-TCR interactions relied on the co-receptors of the CD8 molecule. Identification of Qa-1-restricted CD8 ${ }^{+}$Tregs enriched the occurrence and development mechanism of autoimmune disease, providing a theoretical basis for its treatment.

Potential role of $C C$ chemokines expressed by specific $C D 8 \alpha \alpha^{+}$Tregs and the thymus during ovulation. It is widely considered that ovulation may be an inflammatory process $(93,94)$; however, little is known regarding how immune cells participate in this process. Novel CD8 $\alpha \alpha^{+}$Tregs have been identified in the theca of the antral follicles (95). In addition, it has been observed that the ovaries of anovulatory $\mathrm{C}_{31} \mathrm{~F}_{1}$ mice under treatment with estradiol and of nude mice (thymus-free) with low fertility were lacking CD8 $\alpha \alpha^{+}$ Tregs (26). Thymus-expressed chemokine (TECK) has previously been detected in the ovaries and was reported to attract CD8 $\alpha \alpha^{+}$Tregs to the ovaries. However, in anovulatory $\mathrm{C}_{31 \mathrm{~F}_{1}}$ mice, ovarian TECK expression was normal, suggesting that the absence of CD8 $\alpha \alpha^{+}$Treg migration to the ovaries was responsible for the infertility of the mice. Finally, the origin of ovarian CD8 $\alpha \alpha^{+}$Treg was investigated, and it was observed that the migrated ovarian CD $8 \alpha \alpha^{+}$Tregs were able to return to the recipient's thymus $(95,26)$. Therefore, it is reasonable to speculate that ovarian $\mathrm{CD} 8 \alpha \alpha^{+}$Tregs involved in ovulation-associated inflammation may originate from the thymus. Pathological alterations of the thymus may cause ovarian-associated inflammation, thus revealing a potential mechanism of ovaritis and providing a novel strategy for ovarian-associated inflammation.

Immune regulation of novel Qa-1-restricted CD8 $\alpha \alpha^{+} T C R \alpha \beta^{+}$ Tregs. $\mathrm{CD}^{+}$Tregs exhibit a gene expression spectrum similar to innate lymophoid cells, which is shared by mouse intraepithelial lymphocytes and thymus $\operatorname{CD} 8 \alpha \alpha^{+} \mathrm{TCR} \alpha \beta^{+}$Tregs. However, the expression of several key regulatory molecules has been reported to be different among these cells $(96,97)$. Specifically, CD8 $\alpha \alpha^{+}$TCR $\alpha \beta^{+}$Tregs express a higher level of certain natural killer cell-associated receptors and tumor necrosis factor superfamily molecules. Their difference from the traditional MHC-Ia-like-restricted T cells lies in several lines of evidence. Firstly, they have been observed to activate $\mathrm{V} \beta 8.2 \mathrm{CD}^{+} \mathrm{T}$ cells and control the experimental autoimmune cerebrospinal meningitis $(98,99)$. In addition, they express only $\mathrm{CD} 8 \alpha \alpha^{+}$dimers, which recognize the conserved region peptides of the TCR V $\beta 8.2$ chain in Qa-1a. Furthermore, they secrete only type I cell factor cytokines, but not IL-2 $(84,100)$. In conclusion, $\mathrm{CD} 8 \alpha \alpha^{+} \mathrm{TCR} \alpha \beta^{+}$Tregs prevented autoimmunity caused by adoptive cell transfer or in vivo activation of $\mathrm{CD}^{+}$ $\mathrm{T}$ cells. Notably, this negative feedback regulation is directed against activated $\mathrm{T}$ cells, which provides a novel strategy for the treatment of autoimmune diseases and transplant rejection.

$C D 8^{+}$Tregs inhibit follicular helper T cells, and thereby serve a vital role in self-tolerance. The ability of excess tissue and organs to incite a strong immune response depends on the clearance of autoreactive T or B lymphocytes. However, immature and mature autoreactive $\mathrm{T}$ and $\mathrm{B}$ cells are not thoroughly cleared, and may require an effort from cell reprograming to suppress the immune response. Notably, a sublineage of $\mathrm{CD}^{+}$ Tregs is necessary for the maintenance of self-tolerance and the prevention of autoimmune diseases in mice (101-103). The interruption of gene functions associated with the interaction between these $\mathrm{CD}^{+} \mathrm{T}$ cells and $\mathrm{Qa}-1^{+}$follicular helper $\mathrm{T}$ cells can to lead to the development of systemic lupus erythematosus, indicating that these sublineage $\mathrm{T}$ cells serve an important role in the regulation of immune response, as well as in the surveillance of immune tolerance (104-106). 


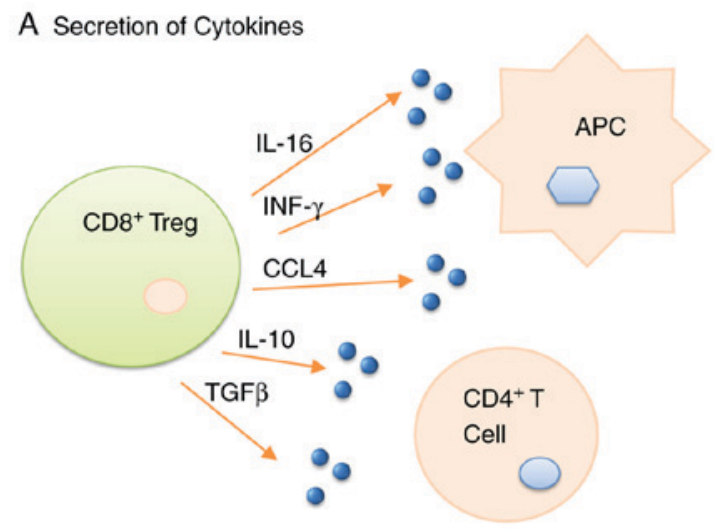

B Rendering APCs Tolerogenic

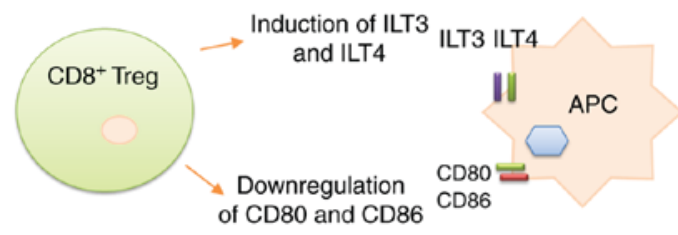

C Cell-contact dependent
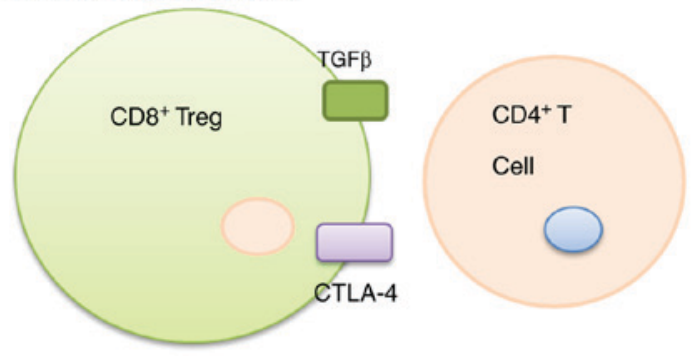

D Cytotoxicity
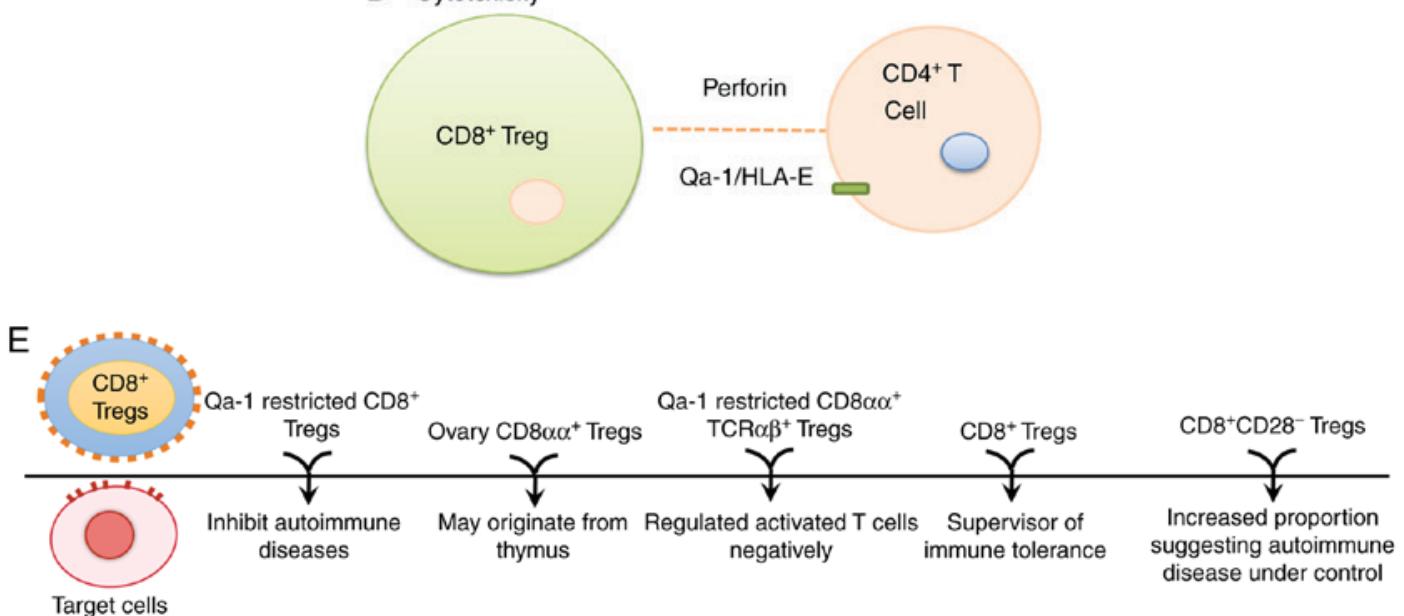

Figure 1. (A) $\mathrm{CD}^{+}$Tregs secret various inhibitory cytokines and chemokines, including IL-10, TGF- $\beta$, IL-16, IFN- $\gamma$ and CCL4. (B) CD8 ${ }^{+}$Tregs render the antigen-presenting cells tolerogenic and anti-inflammatory by the induction ILT3 and ILT4, or through the downregulation of CD80 and CD86 on APCs. (C) $\mathrm{CD}^{+}$Tregs serve an inhibitory function, in which TGF- $\beta$ and CTLA-4 expressed on the cell surface are the key factors. (D) The cytotoxicity of CD8 ${ }^{+}$ Tregs depends on the expression of the major histocompatibility complex class Ib molecule Qa-1 in mice and HLA-E in humans. (E) Recent advances in CD8 ${ }^{+}$Treg research. Treg, T regulatory cell; IL, interleukin, TGF, transforming growth factor; IFN, interferon; CCL4, chemokine (C-C motif) ligand 4; ILT, immunoglobulin-like transcript; APC, antigen-presenting cell; CTLA-4, cytotoxic T-lymphocyte associated protein 4; TCR, T cell receptor.

Association between $C D 8^{+}$Tregs and autoimmune diseases . A decreased number or impaired function of $\mathrm{CD} 8^{+}$Tregs has been observed in patients with autoimmune diseases, including multiple sclerosis, localized ileitis and myasthenia gravis recurrence. The immunosuppressive effect of $\mathrm{CD} 8{ }^{+} \mathrm{CD} 28^{-}$Tregs has also been confirmed by in vitro experiments (107-110). In addition, Rådinger et al has reported that $\mathrm{CD}^{+}$Tregs can also regulate the occurrence and development of allergic reactions by decreasing the number of chemokines and the recruitment of 
eosinophils (111). These alterations occurred both prior to and following allergic reactions in order to reduce the body's immune reactivity $(112,113)$. A preliminary study on a $\mathrm{CD}^{+}$ $\mathrm{T}$ cell subpopulation in the peripheral blood has correlated the changes in cell distributions to the immune system disorder in patients with systemic lupus erythematosus. In particular, the proportion of $\mathrm{CD}^{+} \mathrm{CD} 28^{-}$Tregs subset, as well as the $\mathrm{CD} 8^{+} \mathrm{CD} 28 / \mathrm{CD}^{+} \mathrm{CD} 28^{+} \mathrm{T}$ cell ratio, may reflect the disorder of cellular immune function. Furthermore, the increase of $\mathrm{CD}^{+} \mathrm{CD} 28^{-}$Tregs has been demonstrated to be associated with the control of disease progress (114-118). Therefore, monitoring the proportion of CD8 ${ }^{+} \mathrm{CD} 28^{-}$Tregs may help to judge the progression of the disease, while an increased proportion of $\mathrm{CD} 8^{+} \mathrm{CD} 28^{-}$Tregs indicates that the autoimmune disease is under control.

$\mathrm{CD}^{+}$Tregs and other diseases. $\mathrm{CD}^{+}{ }^{+}$Foxp $3^{+}$Tregs existing in a prostate tumor have been reported to inhibit the immune responses (119), thus improving the possibility that the manipulation of $\mathrm{CD}^{+}{ }^{+} \mathrm{Foxp}^{+}$Tregs function may raise the efficiency of immunotherapy for prostate tumor patients. Furthermore, the tumor: Whole body ratio of $\mathrm{CD}^{+}$Tregs is associated with the prognosis of cancer patients, including in ovarian and cervical cancer among others $(120,121)$. A high $\mathrm{CD}^{+}$Treg ratio in the tumor mass may indicate a favorable prognosis. Additionally, $\mathrm{CD}^{+}$Tregs can be recruited into the central nervous system during neuroinflammation. However, the recruitment of $\mathrm{CD}^{+}$ Tregs into the inflammation organs depends on the level of B7-H1 on immunogenic DCs (73). This knowledge may be applied in the development of therapies based on DCs and $\mathrm{CD}^{+}$Tregs for neuroinflammation diseases.

\section{Summary and applications}

Currently, several issues remain unaddressed regarding the functions of Tregs and the corresponding research methodology $(21,23)$. Firstly, phenotype identification and a functional/mechanistic study of $\mathrm{CD}^{+}$Tregs have to be further conducted in different experiment systems. In addition, it remains unclear whether different $\mathrm{CD} 8^{+}$cell subpopulations originate from common precursor cells. Finally, the application of $\mathrm{CD}^{+}$Tregs can be further explored in the scenarios of prevention, diagnosis and clinical treatment of diseases.

Thus far, relatively well-studied and well-recognized $\mathrm{CD} 8^{+}$Tregs include natural $\mathrm{CD} 8^{+} \mathrm{CD} 28^{-} \mathrm{T}$ cells, as well as the induced $\mathrm{CD} 8^{+} \mathrm{CD} 28^{-}, \mathrm{CD}^{+} \mathrm{CD} 25^{+}$and $\mathrm{CD} 8^{+} \mathrm{CD} 122^{+} \mathrm{T}$ cells. A systematic analysis on the transcription profile of these $\mathrm{CD} 8^{+}$ Tregs identified CD $25^{+} \mathrm{CD} 28^{-}$to be the most common surface marker $(5,122)$. Other surface markers include FoxP3, CD103, CD122 and CTLA-4 (49,123).

Studies on $\mathrm{CD}^{+}$Tregs are of great value for human disease treatment, and thereby attract increasing researchers into this field. Investigating this group of cells may provide novel ideas for immune regulation and immune intervention. Furthermore, this may elucidate the pathogenesis of associated disease and offer an objective index to their diagnosis, treatment and evaluation. We believe that studies on $\mathrm{CD}^{+}$ Tregs will generate broad application prospects in the fields of inflammatory diseases, autoimmune diseases, tumor immunity and transplantation tolerance.

\section{Acknowledgements}

Not applicable.

\section{Funding}

The present study was supported by Project of Natural Scientific Foundation of Guangxi University of Science and Technology (grant no. 174516).

\section{Availability of data and materials}

Not applicable.

\section{Authors' contributions}

YY was responsible for writing original draft, editing, analysis and designing of the work, and interpretation of data for the work. XM performed analysis, editing and validation. RG provided resources and performed review. JZ is mainly responsible for editing of references, reviewing and data analysis for the work. LW provided software asssitance. JY made substantial contributions to the study design and acquisition and analysis of data. In addition JY was responsible for providing supervision and ensuring that questions related to the accuracy or integrity of any part of the work were appropriately investigated and resolved.

\section{Ethics approval and consent to participate}

Not applicable.

\section{Consent for publication}

Not applicable.

\section{Competing interests}

The authors declare that they have no competing interests.

\section{References}

1. Andersen MH: Immune regulation by self-recognition: Novel possibilities for anticancer immunotherapy. J Natl Cancer Inst 107: pii: djv154, 2015.

2. Andersen MH: Novel understanding of self-reactive T cells. Oncoimmunology 5: e1083672, 2015.

3. Munir Ahmad S, Martinenaite E, Hansen M, Junker N, Borch TH, Met Ö, Donia M, Svane IM and Andersen MH: PD-L1 peptide co-stimulation increases immunogenicity of a dendritic cell-based cancer vaccine. Oncoimmunology 5: e1202391, 2016.

4. Markman JL and Shiao SL: Impact of the immune system and immunotherapy in colorectal cancer. J Gastrointest Oncol 6: 208-223, 2015.

5. Sun Q, Burton RL and Lucas KG: Cytokine production and cytolytic mechanism of CD4(+) cytotoxic T lymphocytes in ex vivo expanded therapeutic Epstein-Barr virus-specific T-cell cultures. Blood 99: 3302-3309, 2002

6. Guo H, Cheng Y, Shapiro J and McElwee K: The role of lymphocytes in the development and treatment of alopecia areata. Expert Rev Clin Immunol 11: 1335-1351, 2015.

7. Lemke H: Antigen receptor-intrinsic non-self: The key to understanding regulatory lymphocyte-mediated idiotypic control of adaptive immune responses. Crit Rev Immunol 36: 13-56, 2016. 
8. Plasilova M, Risitano A and Maciejewski JP: Application of the molecular analysis of the T-cell receptor repertoire in the study of immune-mediated hematologic diseases. Hematology 8: 173-181, 2003.

9. Lopez-Pedrera C, Perez-Sanchez C, Ramos-Casals M, Santos-Gonzalez M, Rodriguez-Ariza A and Cuadrado MJ: Cardiovascular risk in systemic autoimmune diseases: Epigenetic mechanisms of immune regulatory functions. Clin Dev Immunol 2012: 974648, 2012.

10. Amaya-Amaya J, Montoya-Sanchez L and Rojas-Villarraga A Cardiovascular involvement in autoimmune diseases. Biomed Res Int 2014: 367359, 2014

11. Michelsen SW, Soborg B, Diaz LJ, Hoff ST, Agger EM, Koch A, Rosenkrands I, Wohlfahrt J and Melbye M: The dynamics of immune responses to Mycobacterium tuberculosis during different stages of natural infection: A longitudinal study among Greenlanders. PLoS One 12: e0177906, 2017.

12. Hunniger K, Lehnert T, Bieber K, Martin R, Figge MT and Kurzai O: A virtual infection model quantifies innate effector mechanisms and Candida albicans immune escape in human blood. PLoS Comput Biol 10: e1003479, 2014.

13. Gounder K, Padayachi N, Mann JK, Radebe M, Mokgoro M, van der Stok M, Mkhize L, Mncube Z, Jaggernath M, Reddy T, et al: High frequency of transmitted HIV-1 Gag HLA class I-driven immune escape variants but minimal immune selection over the first year of clade C infection. PLoS One 10: e0119886, 2015.

14. Huang SS, Banner D, Degousee N, Leon AJ, Xu L, Paquette SG, Kanagasabai T, Fang Y, Rubino S, Rubin B, et al: Differential pathological and immune responses in newly weaned ferrets are associated with a mild clinical outcome of pandemic $2009 \mathrm{H} 1 \mathrm{~N} 1$ infection. J Virol 86: 13187-13201, 2012.

15. Bourke CD, Maizels RM and Mutapi F: Acquired immune heterogeneity and its sources in human helminth infection. Parasitology 138: 139-159, 2011

16. Furman D and Davis MM: New approaches to understanding the immune response to vaccination and infection. Vaccine 33 5271-5281, 2015

17. Redgrove KA and McLaughlin EA: The role of the immune response in chlamydia trachomatis infection of the male genital tract: A double-edged sword. Front Immunol 5: 534, 2014

18. Kotzamanis K, Angulo A and Ghazal P: Infection homeostasis: Implications for therapeutic and immune programming of metabolism in controlling infection. Med Microbiol Immunol 204: 395-407, 2015.

19. Gershon RK and Kondo K: Cell interactions in the induction of tolerance: The role of thymic lymphocytes. Immunology 18 : 723-737, 1970

20. Afonina IS, Zhong Z, Karin M and Beyaert R: Limiting inflammation-the negative regulation of NF- $x \mathrm{~B}$ and the NLRP3 inflammasome. Nat Immunol 18: 861-869, 2017.

21. Dinesh RK, Skaggs BJ, La Cava A, Hahn BH and Singh RP: $\mathrm{CD}^{+}$Tregs in lupus, autoimmunity, and beyond. Autoimmun Rev 9: 560-568, 2010.

22. Emregul E, David A, Balthasar JP and Yang VC: A GPIIb/IIIa bioreactor for specific treatment of immune thrombocytopenic purpura, an autoimmune disease. Preparation, in vitro characterization, and preliminary proof-of-concept animal studies. J Biomed Mater Res A 75: 648-655, 2005.

23. Smith TR and Kumar V: Revival of $\mathrm{CD}^{+}$Treg-mediated suppression. Trends Immunol 29: 337-342, 2008

24. Liu D, Li G, Avella DM, Kimchi ET, Kaifi JT, Rubinstein MP, Camp ER, Rockey DC, Schell TD and Staveley-O'Carroll KF: Sunitinib represses regulatory $\mathrm{T}$ cells to overcome immunotolerance in a murine model of hepatocellular cancer. Oncoimmunology 7: e1372079, 2017.

25. Chakraborty S, Panda AK, Bose S, Roy D, Kajal K, Guha D and Sa G: Transcriptional regulation of FOXP3 requires integrated activation of both promoter and CNS regions in tumor-induced CD8+ Treg cells. Sci Rep 7: 1628, 2017.

26. Zhou C, Wu J, Borillo J, Torres L, McMahon J and Lou YH: Potential roles of a special CD8 alpha alpha+ cell population and $\mathrm{CC}$ chemokine thymus-expressed chemokine in ovulation related inflammation. J Immunol 182: 596-603, 2009.

27. Tang X, Maricic I, Purohit N, Bakamjian B, Reed-Loisel LM, BeestonT,JensenPand KumarV:Regulation of immunityby anove population of Qa-1-restricted CD8alphaalpha+TCRalphabeta+ T cells. J Immunol 177: 7645-7655, 2006.

28. Bian Y, Shang S, Siddiqui S, Zhao J, Joosten SA, Ottenhoff THM, CantorHandWang CR:MHCIbmoleculeQa-1 presents Mycobacterium tuberculosis peptide antigens to CD8+ T cells and contributes to protection against infection. PLoS Pathog 13: e1006384, 2017.
29. Takada K, Kondo K and Takahama Y: Generation of peptides that promote positive selection in the thymus. J Immunol 198: 2215-2222, 2017

30. Mohammed Ali HH and Drela N: Role of thymic B cells in the development of thymus-derived regulatory $\mathrm{T}$ cell in vitro. Immunol Lett 185: 56-63, 2017.

31. Talotta R, Atzeni F, Batticciotto A, Benucci M, Bongiovanni S and Sarzi-Puttini P: Biological agents in rheumatoid arthritis: A cross-link between immune tolerance and immune surveillance. Curr Rheumatol Rev, 2016.

32. Huang G, Xu J, Lefever DE, Glenn TC, Nagy T and Guo TL: Genistein prevention of hyperglycemia and improvement of glucose tolerance in adult non-obese diabetic mice are associated with alterations of gut microbiome and immune homeostasis. Toxicol Appl Pharmacol 332: 138-148, 2017.

33. Capece T and Kim M: The role of lymphatic niches in T Cell Differentiation. Mol Cells 39: 515-523, 2016.

34. Yang N, Li Z, Jiao Z, Gu P, Zhou Y, Lu L and Chou KY: A Trichosanthin-derived peptide suppresses type 1 immune responses by TLR2-dependent activation of CD8(+)CD28(-) Tregs. Clin Immunol 153: 277-287, 2014.

35. Vuddamalay Y and van Meerwijk JP: CD28- and CD28lowCD8+ regulatory T cells: Of mice and men. Front Immunol 8: 31, 2017.

36. Morimoto C, Takeuchi $\mathrm{T}$ and Schlossman SF: Characterization of the CD8+CD45R+(2H4+) suppressor effector cell. Clin Exp Rheumatol 7 (Suppl 3): S3-S7, 1989.

37. Takeuchi T, Rudd CE, Tanaka S, Rothstein DM, Schlossman SF and Morimoto C: Functional characterization of the CD45R (2H4) molecule on CD8 (T8) cells in the autologous mixed lymphocyte reaction system. Eur J Immunol 19: 747-755, 1989.

38. Raziuddin S and Elawad ME: Immunoregulatory CD4+ CD45R+ suppressor/inducer T lymphocyte subsets and impaired cell-mediated immunity in patients with Down's syndrome. Clin Exp Immunol 79: 67-71, 1990.

39. Wei S, Kryczek I, Zou L, Daniel B, Cheng P, Mottram P, Curiel T, Lange A and Zou W: Plasmacytoid dendritic cells induce CD8+ regulatory $\mathrm{T}$ cells in human ovarian carcinoma. Cancer Res 65 : 5020-5026, 2005

40. Wu J, Li S, Yang Y, Zhu S, Zhang M, Qiao Y, Liu YJ and Chen J: TLR-activated plasmacytoid dendritic cells inhibit breast cancer cell growth in vitro and in vivo. Oncotarget 8: 11708-11718,2017.

41. Kourtzelis I and Rafail S: The dual role of complement in cancer and its implication in anti-tumor therapy. Ann Transl Med 4: 265, 2016.

42. Chen L, Hasni MS, Jondal M and Yakimchuk K: Modification of anti-tumor immunity by tolerogenic dendritic cells. Autoimmunity 50: 370-376, 2017.

43. Wang L: Adaptive Treg generation by DCs and their functional analysis. Methods Mol Biol 595: 403-412, 2010.

44. Gao JF, McIntyre MS, Juvet SC, Diao J, Li X, Vanama RB, Mak TW, Cattral MS and Zhang L: Regulation of antigen-expressing dendritic cells by double negative regulatory T cells. Eur J Immunol 41: 2699-2708, 2011.

45. Suciu-Foca N, Manavalan JS, Scotto L, Kim-Schulze S, Galluzzo S, Naiyer AJ, Fan J, Vlad G and Cortesini R: Molecular characterization of allospecific $\mathrm{T}$ suppressor and tolerogenic dendritic cells: Review. Int Immunopharmacol 5: 7-11, 2005.

46. Song ZY, Yamasaki R, Kawano Y, Sato S, Masaki K, Yoshimura S, Matsuse D, Murai H, Matsushita T and Kira J: Peripheral blood $\mathrm{T}$ cell dynamics predict relapse in multiple sclerosis patients on fingolimod. PLoS One 10: e0124923, 2015.

47. Hendrikx TK, Velthuis JH, Klepper M, van Gurp E, Geel A, Schoordijk W, Baan CC and Weimar W: Monotherapy rapamycin allows an increase of CD4 CD25 FoxP3 T cells in renal recipients. Transpl Int 22: 884-891, 2009.

48. Assadiasl S, Ahmadpoor P, Nafar M, Lessan Pezeshki M, Pourrezagholi F, Parvin M, Shahlaee A, Sepanjnia A, Nicknam MH and Amirzargar A: Regulatory T cell subtypes and TGF-beta1 gene expression in chronic allograft dysfunction. Iran J Immunol 11: 139-152, 2014

49. Negrini S, Fenoglio D, Parodi A, Kalli F, Battaglia F, Nasi G, Curto M, Tardito S, Ferrera F and Filaci G: Phenotypic alterations involved in CD8+ Treg impairment in systemic sclerosis. Front Immunol 8: 18, 2017.

50. Velasquez-Lopera MM, Correa LA and Garcia LF: Human spleen contains different subsets of dendritic cells and regulatory T lymphocytes. Clin Exp Immunol 154: 107-114, 2008.

51. Wang B, Jiao Z, Shao X, Lu L, Yang N, Zhou X, Xin L, Zhou Y and Chou KY: Phenotypic alterations of dendritic cells are involved in suppressive activity of trichosanthin-induced CD8+CD28- regulatory T cells. J Immunol 185: 79-88, 2010. 
52. Nikoueinejad H, Amirzargar A, Sarrafnejad A, Einollahi B Nafar M, Ahmadpour P, Pour-Reze-Gholi F, Sehat O and Lesanpezeshki M: Dynamic changes of regulatory $\mathrm{T}$ cell and dendritic cell subsets in stable kidney transplant patients: A prospective analysis. Iran J Kidney Dis 8: 130-138, 2014.

53. Brunkow ME, Jeffery EW, Hjerrild KA, Paeper B, Clark LB, Yasayko SA, Wilkinson JE, Galas D, Ziegler SF and Ramsdell F: Disruption of a new forkhead/winged-helix protein, scurfin, results in the fatal lymphoproliferative disorder of the scurfy mouse. Nat Genet 27: 68-73, 2001.

54. Ochs HD, Ziegler SF and Torgerson TR: FOXP3 acts as a rheostat of the immune response. Immunol Rev 203: 156-164, 2005.

55. Niemz J, Kliche S, Pils MC, Morrison E, Manns A, Freund C, Crittenden JR, Graybiel AM, Galla M, Jänsch L, et al: The guanine-nucleotide exchange factor Caldag gefi fine-tunes functional properties of regulatory T cells. Eur J Microbiol Immunol (Bp) 7: 112-126, 2017.

56. Maranduba CM, De Castro SB, de Souza GT, Rossato C, da Guia FC, Valente MA, Rettore JV, Maranduba CP, de Souza CM, do Carmo AM, et al: Intestinal microbiota as modulators of the immune system and neuroimmune system: Impact on the host health and homeostasis. J Immunol Res 2015: 931574, 2015 .

57. Fontenot JD, Gavin MA and Rudensky AY: FOXP3 programs the development and function of CD4+CD25+ regulatory T cells Nat Immunol 4: 330-336, 2003.

58. Bin Dhuban K, Kornete M, S Mason E and Piccirillo CA: Functional dynamics of Foxp3 ${ }^{+}$regulatory $\mathrm{T}$ cells in mice and humans. Immunol Rev 259: 140-158, 2014.

59. Cosmi L, Liotta F, Lazzeri E, Francalanci M, Angeli R, Mazzinghi B, Santarlasci V, Manetti R, Vanini V, Romagnani $\mathrm{P}$, et al: Human CD8+CD25+ thymocytes share phenotypic and functional features with $\mathrm{CD} 4+\mathrm{CD} 25+$ regulatory thymocytes. Blood 102: 4107-4114, 2003.

60. Maslanka T, Ziolkowska N, Ziolkowski H and Malaczewska J: CD25+CD127+Foxp3 - cells represent a major subpopulation of CD8+ T cells in the eye chambers of normal mice. PLoS One 12 e0170021, 2017.

61. Jun C, Ke W, Qingshu L, Ping L, Jun D, Jie L, Bo C and Su M: Protective effect of CD4(+)CD25(high)CD127(low) regulatory $\mathrm{T}$ cells in renal ischemia-reperfusion injury. Cell Immunol 289: 106-111, 2014

62. Su H, Longhi MS, Wang P, Vergani D and Ma Y: Human CD4+CD25(high)CD127 (low/neg) regulatory T cells. Methods Mol Biol 806: 287-299, 2012

63. Simonetta F, Chiali A, Cordier C, Urrutia A, Girault I, Bloquet S, Tanchot $C$ and Bourgeois C: Increased CD127 expression on activated FOXP3+CD4+ regulatory T cells. Eur J Immunol 40 $2528-2538,2010$

64. Rodriguez-Perea AL, Arcia ED, Rueda CM and Velilla PA: Phenotypical characterization of regulatory $T$ cells in humans and rodents. Clin Exp Immunol 185: 281-291, 2016.

65. Zhang HY, Yan KX, Huang Q, Ma Y, Fang X and Han L: Target tissue ectoenzyme CD39/CD73-expressing Foxp3+ regulatory T cells in patients with psoriasis. Clin Exp Dermatol 40: 182-191, 2015.

66. Allard B, Longhi MS, Robson SC and Stagg J: The ectonucleotidases CD39 and CD73: Novel checkpoint inhibitor targets. Immunol Rev 276: 121-144, 2017.

67. Bono MR, Fernandez D, Flores-Santibanez F, Rosemblatt M and Sauma D: CD73 and CD39 ectonucleotidases in T cell differentiation: Beyond immunosuppression. FEBS Lett 589: 3454-3460, 2015

68. Matyash M, Zabiegalov O, Wendt S, Matyash V and Kettenmann H: The adenosine generating enzymes CD39/CD73 control microglial processes ramification in the mouse brain. PLoS One 12: e0175012, 2017.

69. Hasan D, Blankman P and Nieman GF: Purinergic signalling links mechanical breath profile and alveolar mechanics with the pro-inflammatory innate immune response causing ventilation-induced lung injury. Purinergic Signal 13: 363-386, 2017.

70. Drakes ML and Stiff PJ: Harnessing immunosurveillance: Current developments and future directions in cancer immunotherapy. Immunotargets Ther 3: 151-165, 2014

71. Stallone G, Infante B, Di Lorenzo A, Rascio F, Zaza G and Grandaliano G: mTOR inhibitors effects on regulatory T cells and on dendritic cells. J Transl Med 14: 152, 2016.

72. Oberg HH, Juricke M, Kabelitz D and Wesch D: Regulation of T cell activation by TLR ligands. Eur J Cell Biol 90: 582-592, 2011

73. Su J, Xie Q, Xu Y, Li XC and Dai Z: Role of CD8(+) regulatory $\mathrm{T}$ cells in organ transplantation. Burns Trauma 2: 18-23, 2014.
74. Ferguson AR and Engelhard VH: CD8 T cells activated in distinct lymphoid organs differentially express adhesion proteins and coexpress multiple chemokine receptors. J Immunol 184: 4079-4086, 2010

75. Croft M and Siegel RM: Beyond TNF: TNF superfamily cytokines as targets for the treatment of rheumatic diseases. Nat Rey Rheumatol 13: 217-233, 2017.

76. Xu Z, Ho S, Chang CC, Zhang QY, Vasilescu ER, Vlad G and Suciu-Foca N: Molecular and cellular characterization of human CD8 T suppressor cells. Front Immunol 7: 549, 2016.

77. Parkes MD, Halloran PF and Hidalgo LG: Mechanistic sharing between NK cells in ABMR and effector T cells in TCMR. Am J Transplant 18: 63-73, 2017.

78. Nagy E, Lei Y, Martinez-Martinez E, Body SC, Schlotter F, Creager M, Assmann A, Khabbaz K, Libby P, Hansson GK, et al: Interferon-gamma released by activated CD8+ T lymphocytes impairs the calcium resorption potential of osteoclasts in calcified human aortic valves. Am J Pathol 187: 1413-1425, 2017.

79. Hasegawa H, Kawahata K, Mizoguchi F, Okiyama N, Miyasaka N and Kohsaka H: Direct suppression of autoaggressive CD8+ $\mathrm{T}$ cells with CD80/86 blockade in CD8+ T cell-mediated polymyositis models of mice. Clin Exp Rheumatol 35: 593-597, 2017.

80. Beyranvand Nejad E, van der Sluis TC, van Duikeren S, Yagita H, Janssen GM, van Veelen PA, Melief CJ, van der Burg SH and Arens R: Tumor eradication by cisplatin is sustained by CD80/86-mediated costimulation of CD8+ T cells. Cancer Res 76: 6017-6029, 2016.

81. Pierini A, Schneidawind D, Nishikii $\mathrm{H}$ and Negrin RS: Regulatory $\mathrm{T}$ cell immunotherapy in immune-mediated diseases. Curr Stem Cell Rep 1: 177-186, 2015.

82.Long SA, Thorpe J, DeBerg HA, Gersuk V, Eddy J, Harris KM, Ehlers M, Herold KC, Nepom GT and Linsley PS: Partial exhaustion of CD8 T cells and clinical response to teplizumab in new-onset type 1 diabetes. Sci Immunol 1: pii: eaai7793, 2016.

83. Joosten SA, Sullivan LC and Ottenhoff TH: Characteristics of HLA-E restricted T-cell responses and their role in infectious diseases. J Immunol Res 2016: 2695396, 2016.

84. Varthaman A, Clement M, Khallou-Laschet J, Fornasa G, Gaston AT, Dussiot M, Caligiuri G, Cantor H, Kaveri S and Nicoletti A: Physiological induction of regulatory Qa-1-restricted CD8+ T cells triggered by endogenous CD4+ T cell responses. PLoS One 6: e21628, 2011

85. Sinha S, Itani FR and Karandikar NJ: Immune regulation of multiple sclerosis by CD8+ T cells. Immunol Res 59: 254-265, 2014.

86. Leavenworth JW, Tang X, Kim HJ, Wang X and Cantor H: Amelioration of arthritis through mobilization of peptide-specific CD8+ regulatory T cells. J Clin Invest 123: 1382-1389, 2013

87. Kambayashi T, Kraft-Leavy JR, Dauner JG, Sullivan BA, Laur O and Jensen PE: The nonclassical MHC class I molecule Qa-1 forms unstable peptide complexes. J Immunol 172: 1661-1669, 2004.

88. Jiang H: The Qa-1 dependent CD8+ T cell mediated regulatory pathway. Cell Mol Immunol 2: 161-167, 2005.

89. Chen L, Reyes-Vargas E, Dai H, Escobar H, Rudd B, Fairbanks J, Ho A, Cusick MF, Kumánovics A, Delgado J, et al: Expression of the mouse MHC class Ib H2-T11 gene product, a paralog of H2-T23 (Qa-1) with shared peptide-binding specificity. J Immunol 193: 1427-1439, 2014.

90. Jensen PE, Sullivan BA, Reed-Loisel LM and Weber DA Qa-1, a nonclassical class I histocompatibility molecule with roles in innate and adaptive immunity. Immunol Res 29: 81-92, 2004

91. Ramsingh AI, Manley K, Rong Y, Reilly A and Messer A: Transcriptional dysregulation of inflammatory/immune pathways after active vaccination against Huntington's disease. Hum Mol Genet 24: 6186-6197, 2015.

92. Shiina T, Blancher A, Inoko H and Kulski JK: Comparative genomics of the human, macaque and mouse major histocompatibility complex. Immunology 150: 127-138, 2017.

93. Chiswick EL, Mella JR, Bernardo J and Remick DG: Acute-phase deaths from murine polymicrobial sepsis are characterized by innate immune suppression rather than exhaustion. J Immunol 195: 3793-3802, 2015

94. O'Leary S, Lloyd ML, Shellam GR and Robertson SA: Immunization with recombinant murine cytomegalovirus expressing murine zona pellucida 3 causes permanent infertility in BALB/c mice due to follicle depletion and ovulation failure. Biol Reprod 79: 849-860, 2008. 
95. Cheng MH and Nelson LM: Mechanisms and models of immune tolerance breakdown in the ovary. Semin Reprod Med 29: 308-316, 2011.

96.Li XL, Menoret S, Bezie S, Caron L, Chabannes D, Hill M Halary F, Angin M, Heslan M, Usal C, et al: Mechanism and localization of CD8 regulatory $\mathrm{T}$ cells in a heart transplant model of tolerance. J Immunol 185: 823-833, 2010.

97. Nambu Y, Hayashi T, Jang KJ, Aoki K, Mano H, Nakano K, Osato $\mathrm{M}$, Takahashi $\mathrm{K}$, Itoh $\mathrm{K}$, Teramukai $\mathrm{S}$, et al: In situ differentiation of CD8 $\alpha \alpha \mathrm{T}$ cells from CD4 T cells in peripheral lymphoid tissues. Sci Rep 2: 642, 2012.

98. Tang X, Maricic I and Kumar V: Anti-TCR antibody treatment activates a novel population of nonintestinal CD8 alpha alpha+ TCR alpha beta+ regulatory $\mathrm{T}$ cells and prevents experimental autoimmune encephalomyelitis. J Immunol 178: 6043-6050, 2007.

99. Kumar V and Sercarz E: An integrative model of regulation centered on recognition of TCR peptide/MHC complexes. Immunol Rev 182: 113-121, 2001.

100. Ge PL, Ma LP, Wang W, Li Y and Zhao WM: Inhibition of collagen-induced arthritis by DNA vaccines encoding TCR Vbeta5.2 and TCR Vbeta8.2. Chin Med J (Engl) 122: 1039-1048, 2009.

101. Xu H, Wang X, Malam N, Aye PP, Alvarez X, Lackner AA and Veazey RS: Persistent simian immunodeficiency virus infection drives differentiation, aberrant accumulation, and latent infection of germinal center follicular T helper cells. J Virol 90 1578-1587, 2015.

102. Bruno F, Fornara C, Zelini P, Furione M, Carrara E, Scaramuzzi L, Cane I, Mele F, Sallusto F, Lilleri D, et al: Follicular helper T-cells and virus-specific antibody response in primary and reactivated human cytomegalovirus infections of the immunocompetent and immunocompromised transplant patients. J Gen Virol 97: 1928-1941, 2016.

103. Muema DM, Macharia GN, Olusola BA, Hassan AS, Fegan GW, Berkley JA, Urban BC and Nduati EW: Proportions of circulating follicular helper $\mathrm{T}$ cells are reduced and correlate with memory B cells in HIV-infected children. PLoS One 12 e0175570, 2017

104. Sugimoto T and Watanabe T: Follicular Lymphoma: The role of the tumor microenvironment in prognosis. J Clin Exp Hematop 56: 1-19, 2016.

105. Kurita D, Miyoshi H, Yoshida N, Sasaki Y, Kato S, Niino D, Sugita Y, Hatta Y, Takei M, Makishima M, et al: A clinicopathologic study of lennert lymphoma and possible prognostic factors: the importance of follicular helper T-cell markers and the association with angioimmunoblastic T-cell lymphoma. Am J Surg Pathol 40: 1249-1260, 2016.

106. Miles B, Miller SM, Folkvord JM, Levy DN, Rakasz EG, Skinner PJ and Connick E: Follicular regulatory CD8 T cells impair the germinal center response in SIV and ex vivo HIV infection. PLoS Pathog 12: e1005924, 2016.

107. Tsai S, Clemente-Casares X and Santamaria P: CD8(+) Tregs in autoimmunity: Learning 'self'-control from experience. Cell Mol Life Sci 68: 3781-3795, 2011

108. Krausz LT, Major ZZ, Muresanu DF, Chelaru E, Nocentini G and Riccardi C: Characterization of CD4+ and CD8+ Tregs in a Hodgkin's lymphoma patient presenting with myasthenia-like symptoms. Ideggyogy Sz 66: 343-348, 2013.
109. Spadaro M, Montarolo F, Perga S, Martire S, Brescia F, Malucchi S and Bertolotto A: Biological activity of glatiramer acetate on Treg and anti-inflammatory monocytes persists for more than 10 years in responder multiple sclerosis patients. Clin Immunol 181: 83-88, 2017.

110. van Nierop GP, van Luijn MM, Michels SS, Melief MJ, Janssen M, Langerak AW, Ouwendijk WJD, Hintzen RQ and Verjans GMGM: Phenotypic and functional characterization of T cells in white matter lesions of multiple sclerosis patients. Acta Neuropathol 134: 383-401, 2017.

111. Rådinger M, Bossios A, Alm AS, Jeurink P, Lu Y, Malmhäll C, Sjöstrand M and Lötvall J: Regulation of allergen-induced bone marrow eosinophilopoiesis: Role of CD4+ and CD8+ T cells. Allergy 62: 1410-1418, 2007.

112. Zhang H, Kong H, Zeng X, Guo L, Sun X and He S: Subsets of regulatory $\mathrm{T}$ cells and their roles in allergy. J Transl Med 12: $125,2014$.

113. Martin-Orozco E, Norte-Munoz M and Martinez-Garcia J: Regulatory T cells in allergy and asthma. Front Pediatr 5: 117, 2017.

114. Tulunay A, Yavuz S, Direskeneli H and Eksioglu-Demiralp E: CD8+CD28-, suppressive T cells in systemic lupus erythematosus. Lupus 17: 630-637, 2008.

115. Zabinska M, Krajewska M, Koscielska-Kasprzak K and Klinger M: CD3(+)CD8(+)CD28(-) T lymphocytes in patients with lupus nephritis. J Immunol Res 2016: 1058165, 2016.

116. Ceeraz S, Hall C, Choy EH, Spencer J and Corrigall VM: Defective CD8+CD28+ regulatory T cell suppressor function in rheumatoid arthritis is restored by tumour necrosis factor inhibitor therapy. Clin Exp Immunol 174: 18-26, 2013.

117. Mikulkova Z, Praksova P, Stourac P, Bednarik J, Strajtova L, Pacasova R, Belobradkova J, Dite P and Michalek J: Numerical defects in CD8+CD28- T-suppressor lymphocyte population in patients with type 1 diabetes mellitus and multiple sclerosis Cell Immunol 262: 75-79, 2010.

118. Arosa FA: CD8+CD28- T cells: Certainties and uncertainties of a prevalent human T-cell subset. Immunol Cell Biol 80: 1-13, 2002.

119. Sfanos KS and De Marzo AM: Prostate cancer and inflammation: The evidence. Histopathology 60: 199-215, 2012.

120. Mhawech-Fauceglia P, Wang D, Ali L, Lele S, Huba MA, Liu S, and Odunsi K: Intraepithelial $\mathrm{T}$ cells and tumor-associated macrophages in ovarian cancer patients. Cancer Immun 13: 1, 2013.

121. Longoria TC and Tewari KS: Pharmacologic management of advanced cervical cancer: Antiangiogenesis therapy and immunotherapeutic considerations. Drugs 75: 1853-1865, 2015.

122. Liu $\mathrm{H}$, Wang $\mathrm{Y}$, Zeng $\mathrm{Q}$, Zeng YQ, Liang CL, Qiu F, Nie H and Dai Z: Suppression of allograft rejection by CD8+CD122+PD-1+ Tregs is dictated by their Fas ligand-initiated killing of effector $\mathrm{T}$ cells versus Fas-mediated own apoptosis. Oncotarget 8: 24187-24195, 2017.

123. Beres AJ, Haribhai D, Chadwick AC, Gonyo PJ, Williams CB and Drobyski WR: CD8+ Foxp3+ regulatory T cells are induced during graft-versus-host disease and mitigate disease severity. J Immunol 189: 464-474, 2012. 